\title{
'Long Grief, dark Melancholy, hopeless natural Love': Clarissa, Cheyne and Narratives of Body and Soul
}

Clark Lawlor

\section{Summary}

The paper deals with Clarissa's wasting combination of love and religious melancholy, and the way in which ailments of the mind have an immediate effect on the body in this period. George Cheyne's theories of melancholy and hypochondria explain at least some of the mechanisms by which the eighteenth century understood this phenomenon. 'Clarissa' is an important text because it influenced so many later representations of melancholy, especially as it is gendered feminine in Richardson's newly feminised discourse of sensibility.

Keywords: George Cheyne (1671?-1743); Samuel Richardson (1689-1761); love melancholy; religious melancholy; consumption

"You must see that I have been consuming from day to day." Samuel Richardson, Clarissa; or, the History of a Young Lady ${ }^{1}$

Melancholy is a condition that bridges the mind and body in the Early Modern period: medical theorists from Burton onwards assumed this to be the case, and popular or at least non-medical representations of the condition in literature almost always followed the logic of a unified human entity. I will be substantiating this claim in my paper by examining Samuel Richardson's monumental and highly influential novel Clarissa (1751) by way of popular society doctor George Cheyne's writings. Cheyne knew many of the literary figures of his day and certainly inspired them via his theories of melancholy

1 Richardson 1751, vol. 7, XCVIII, 376.

Dr Clark Lawlor, English Division, School of Arts and Social Sciences, University of Northumbria, Lipman Building, Newcastle upon Tyne NE1 8ST, UK (clark.lawlor@northumbria. ac.uk). 
and hypochondria: as manifested in Richardson's Clarissa, Cheyne's feminisation of melancholy became a powerful image of the condition across Europe and America. As I will be explaining, both these medical and literary constructions of melancholy directly and unambiguously connected the sufferings of Clarissa's melancholy soul to her death, the physical nature of which has been variously discussed but never adequately explicated, something I hope to do here. I will argue that Clarissa dies of a melancholic or nervous consumption, a wasting away of her body directly caused by a combination of the connected conditions of love melancholy and religious melancholy, two tropes common in the Renaissance and well described by the likes of Burton.

The eighteenth-century idea of melancholy, although in many ways continuous with previous, Burtonian notions of the condition, especially in its popular manifestations, shifted significantly in its medical conceptualisation. Crudely speaking, at the end of the seventeenth century new modes of medical thinking came into being, notably the partial displacement of the ancient humoural theory for a more mechanistic Newtonian model and then around mid-century a new physiology of the 'nerves' resulting in a medicine predicated upon the unifying concept of 'sensibility'. George Cheyne was of course a crucial purveyor of the ideas of this innovative melancholy sensibility.

In the new eighteenth-century context defined by Cheyne, both the conditions of melancholy and consumption are transformed, via the 'nerves', into a sign of greater sensibility and social distinction, even as he identifies its debilitating effects. If you have a melancholic consumption, he is saying, you are naturally likely to be a person of distinction, and he makes sure we get the point:'I have always foretold, that these Symptoms (especially in tender, delicat, lively young Persons) would terminat in a real sensible Phthisis Pulmonum' if not prevented. If his austere 'cooling' regimen could be applied before the disorder takes too severe a hold, it would preserve 'some of the noblest and brightest Spirits this Sage or Country produces'. The progression from nervous disorder to consumptive illness is also stressed by later physicians of the nerves like the influential Robert Whytt. In his Observations on the nature, causes and cure of those disorders which have been commonly called Nervous, Hypochondriac, or Hysteric (1765), he specifies that 'a phthisis pulmonalis may also be the consequence of nervous disorders, when the morbid matter producing them falls chiefly upon the lungs' ${ }^{3}$. In the same

2 For the broad changes in the medical model, see Schofield 1970,191; for the nerves in particular see Rousseau 1976, 137-157; Spillane 1981.

3 Whytt 1765, 237. 
volume he also identifies the possibility of 'a nervous atrophy' which involves 'a marasmus or sensible wasting of the body' that lacks many of the precise symptoms (such as sweating and fever) of a consumption of the lungs.

Cheyne, like the physicians before him, recognises that the passions can take their toll on the nerves. Chronic passions like 'long Grief, dark Melancholy, hopeless natural Love' and religious melancholy 'waste' and 'wear out' the nervous system ${ }^{4}$. Sudden and violent passions on the other hand can screw up, stretch and bend the nerves in a more immediate manner ${ }^{5}$.

Although Cheyne does not tie down nervous disorders to rigid gender categories, as the late - and greatly missed - Roy Porter has observed, he does conform to general medical and popular expectations about women's greater physical delicacy and tendency to be defined by their bodies rather than minds ${ }^{6}$. Anita Guerrini argues that Cheyne employs a feminised version of body and spirit because of women's special relation to food preparation, their tendency to control their bodies through diet and his advocacy of milk (feminine) over meat (masculine) $)^{7}$. This is part of a more complex picture in which Cheyne's regimen can be seen as advocating a masculine restraint, but the feminised aspect of his writing appealed strongly to writers like Richardson. One reader of Richardson's complained about a passage in Pamela where 'the Gentleman is said to span the Waist of Pamela with his Hands', a literary representation that is 'enough to ruin a Nation of Women by Tight-lacing'8. Bernard Mandeville was unusually uncontroversial when opining that women's nerves were finer, thinner and more fragile than men's, making them more susceptible to the ill-effects of their passions and badly suited to 'abstruse and elaborate thoughts ... that fatigue the Spirits and require a Steadiness and Assiduity of Thinking'. John Mullan has pointed out that Cheyne's description of Samuel Richardson as a 'Hyppo' (hypochondriac) and valetudinarian was laudatory, whereas for women the theoretically enabling discourse of sensibility, with which they seemed to be especially aligned, was all too often a way of denying their mental powers by valorising the primacy of their bodies ${ }^{10}$.

Indeed, the myth that women, with their womb-driven biology, were supposed to be especially susceptible to consumptive love-melancholy persisted with very little adjustment. John Stephens, a doctor who was very likely read

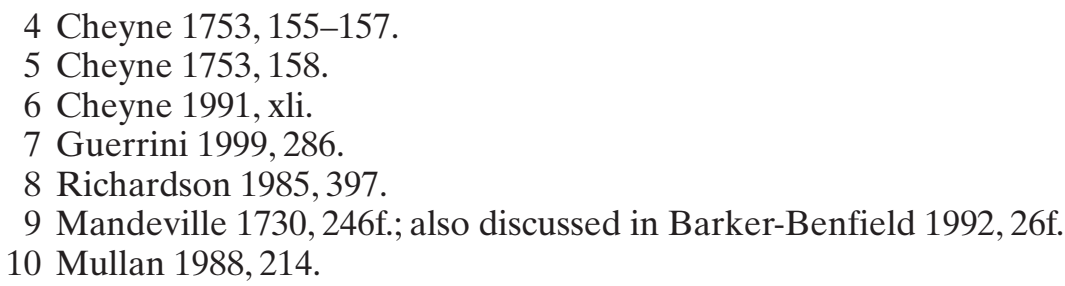


by Laurence Sterne, stated in his Practical Treatise on Consumptions that 'there are many women who, upon the death of a tender husband, dearly beloved infant, or much valued friend, will refute all the comforts, pleasures, and satisfactions of life, and, when in the midst of plenty, sicken and die ${ }^{11}$. The literature of sensibility and sentiment confirms this thesis of female emotional extremity and dependency time and again: loss of the object of desire brings melancholic and consuming grief.

The death of Clarissa, the heroine of Samuel Richardson's novel of the same name, combines elements of the extensive Renaissance love melancholy tradition, aspects of the Protestant good and easy death I have outlined elsewhere, and Cheyne's new discourse of sensibility ${ }^{12}$. Briefly put, consumption was regarded by both Catholics and Protestants alike as being a suitable disease for a Christian because, as Sir Thomas Browne demonstrated in his 'A Letter to a Friend, upon the occasion of the Death of his Intimate Friend', published posthumously in 1690, consumption's supposedly mild symptoms provided a soft and easy death in which one could concentrate on matters spiritual without becoming bogged down in physical suffering ${ }^{13}$.

Clarissa would provide the template for future sentimental, melancholic heroines in both Britain, America and beyond, profoundly influencing representations of female consumptive death in the Romantic and Victorian periods as well as its own century. By providing an extended process of aestheticised consumptive death, Richardson showed a new way of understanding the relationship between disease and gender ${ }^{14}$.

Clarissa's death has been the source of much debate, resistant as it is to any scientific twenty-first-century retrospective diagnosis ${ }^{15}$. Various factors combine to cause Clarissa's disease, the primary one being identified as grief by various people in the novel, including Clarissa herself: 'Death from grief was, she believed, the slowest of deaths ${ }^{16}$. Consumption is crucially chronic in its progress, a sense that its cognate 'decline' echoes. Medical opinion concurs with her self-diagnosis: Goddard the apothecary says that she will recover if she wishes, but

so much grief, as you seem to indulge, is enough to impair the most vigorous health, and to wear out the strongest constitution. ${ }^{17}$

11 Stephens 1761,202. My thanks to DrTom Keymer for bringing Stephens' presence in Sterne's library sale catalogue to my attention.

12 See Lawlor/Suzuki 2000.

13 Browne 1964, 177-196.

14 See Bronfen 1992 and Dijkstra 1986, 6-8.

15 See Stephanson 1988, 267f. Stephanson prepares much of the ground for my own argument in his attribution of Clarissa's death to her sensibility and its physiological attributes.

16 Richardson 1751, vol. 7, XCVIII, 376.

17 Richardson 1751, vol. 6, XCVIII, 400. 
Of course at this point Goddard is mistaken in his belief that his recommended regimen can cure Clarissa because he does not fully comprehend her personal situation and the power of her emotions. Belford anticipates this outcome as he warns Lovelace, the rake whose abduction of Clarissa causes the problem, of the probable effects of his actions:

what I most apprehend, is, that with her own hand, in resentment of the perpetrated outrage, she (like another Lucretia) will assert the purity of her heart: Or, if her piety preserve her from this violence, that wasting grief will soon put a period to her days. ${ }^{18}$

Belford shows that a cultural template already exists for Clarissa's situation: Clarissa grieves for the illegitimate loss of her virginity, but this grief is inserted into the traditional symptoms of love and religious melancholy. After all, she has lost the secular love relationship to which she aspired in the first place; Lovelace was once the object of her desire. Indeed her humane physician has no doubt in declaring that 'her heart's broken: she'll die ... there's no saving her" ${ }^{19}$. As with so many other women in this trope, once her earthly sexual goals are frustrated and her loved one removed for whatever reason, her only respectable option is to turn to religious consolation. The Neoplatonic tradition of secular love leading one to a love of God provides a more philosophically respectable explanation for such a transition. This displacement from secular to religious love does not evade the festering grief felt by Clarissa, however. As Cheyne put it: 'long Grief, dark Melancholy, hopeless natural Love' and religious melancholy 'waste' and 'wear out' the nervous system ${ }^{20}$. Cheyne and the physicians writing before him assumed as a commonplace that grief and love melancholy would result in consumptions, unless the emotion was so strong that suicide cut short the process of wasting.

Clarissa's symptomatology is peculiarly suited to Richardson's requirements for his novel; she suffers from a consumption of a certain form. In Clarissa's death, the symptoms of the disease are minimal although they do change the longer it progresses. The most striking initial aspect is consequent on its psychological motivation: Clarissa herself states that she has 'no appetite $^{21}$. As a result, she loses weight without losing beauty. Other symptoms hint more specifically at a consumption of the lungs. Doctor H. responds to her 'shortness of breath [which she attributed to inward decay precipitated by her late harasses ...]' by recommending the age-old remedy for disorders of the lungs: 'go into the air'. However, because the consumption is a sign of

18 Richardson 1751, vol. 4, LVI, 342.

19 Richardson 1751, vol. 7, LVII, 203.

20 Cheyne 1753, 155-157.

21 Richardson 1751, vol. 6, XCVIII, 400. 
a deeper psychological problem, both physician and patient know that this advice will do no good 'in such a malady as mine'22. This is as technically medical as the representation of her condition is allowed to become: 'shortness of breath' falls far short of many of the terrible problems that could beset those suffering from a consumption of the lungs. There is no spitting of blood, no violent coughing, no nasty matter being expectorated from the lungs, no hectic fevers and, although one could claim a 'facies Hippocratica' or wasted, skeletal features for Clarissa, her beauty is not affected. What we have instead is one of the most symptomless forms of consumption; so symptomless in fact, that a specific medical term is not used as it would detract attention from the emotional and spiritual focus of Clarissa's death as well as allowing a certain latitude in Richardson's manipulation of physical symptoms for narrative effect. It is true that there is medical precedent for this beyond Thomas Browne's description of his friend's death: William Buchan stated in his best-selling popular manual Domestic Medicine that

a Nervous Consumption is a wasting or decay of the whole body, without any considerable degree of fever, cough, or difficulty of breathing. It is attended with indigestion, weakness, and want of appetite etc. [and affects] those who are of a fretful temper. ${ }^{23}$

Richard Brookes' General Practice of Physic of 1765 is happy to concur broadly with this definition, although in a slightly more poetic manner:

a Nervous Atrophy, or Phthisis, is a Wasting of the Body, without any remarkable Fever, cough, or difficulty of Breathing; but is attended with Want of Appetite, and a bad Digestion; when the whole Body grows languid, and is continually falling away. ${ }^{24}$

Clarissa has no hunger, bad digestion and becomes increasingly weak until she can no longer even write. Just as important, her consumption is motivated by 'violent Passions of the Mind', her love and then religious melancholy 25 .

Richardson combines aspects of the various forms along the continuum of consumption to allow different parts of Clarissa's state to manifest themselves in the narrative. Richard Brookes also describes a category of consumptions arising from 'Hypochondriac and Hysterical Affections' that differ from others by 'an Oppression of the Breast, by unusual sadness or Melancholy, by frequent Hysteric Fits, faintings, and other nervous symptoms'26. Clarissa falls under this rubric to a certain extent, a type of love melancholy of the sort that Gideon Harvey describes, and does suffer from a fainting fit when very close to death ${ }^{27}$. This involuntary loss of control of the body

22 Richardson 1751, vol. 7, LXXII, $254 \mathrm{f}$.

23 Buchan 1774, 125.

24 Brookes 1765, vol. 1 - entry on Consumption of the Lungs, 271f.

25 Brookes 1765, vol. 1 - entry on Consumption of the Lungs, 271f.

26 Brookes 1765, vol. 1, 276.

27 Richardson 1751, vol. 7, CII, 402. 
contrasts with Clarissa's fixed determination to master her passions. After the rape she embarks on a slow decline in which she manipulates her death so that it conforms to the traditional Protestant good death, a process that her consumption facilitates.

Another reason no one thinks fit to name Clarissa's disease is because in many ways it was too obvious to her contemporaries, familiar as they were with the Renaissance tradition of love melancholy. J. F. Zückert, a physician writing in 1768, observed that Clarissa's 'slow consumption' is a classic example of the physical consequences of 'heart-break' ${ }^{22}$. However, it is notable that Clarissa herself is far less afraid to discuss her condition than the tactful and usually 'silent' doctors within the novel ${ }^{29}$. It is she who forces the physician to tell her that she has only 'a fortnight or three weeks' to live ${ }^{30}$, she who takes control of her own treatment, and it is she who comes closest to naming her condition technically: she tells Dr H. that 'you must see that I have been consuming from day to day; and now, if I can judge by what I feel in myself ... I cannot continue long ${ }^{31}$. No one has a better understanding of her consuming grief or her melancholy consumptive illness narrative than Clarissa herself: she knows what manner of consumption she suffers and its duration as she claims the privilege of the person of sensibility to prioritise her own experience of her body rather than the more or less 'insensible' analyses of the largely helpless doctors.

Clarissa's symptoms show no real need for medical pain-relief. She becomes increasingly weak, one of the defining characteristics of the languid consumptive, but if anything her experience of disease improves the nearer she gets to death:

I don't think I am dying yet - not actually dying, Mrs. Lovick - for I have no bodily pain - no numbnesses; no signs of immediate death, I think. - And my breath, which used of late to be so short, is now tolerable, my head clear, my intellects free - I think I cannot be dying yet ... yet how merciful is the Almighty, to give His poor creature such a sweet serenity! 'Tis what I have prayed for! ${ }^{32}$

Here we are entering the realm of the consumptive good and easy death that the Protestant divines of the seventeenth century had discussed ${ }^{33}$. The good Christian ideally wished to die a chronic and symptomless death so that affairs temporal and spiritual could be prepared before the day of death: the soul could be in a fit state to ascend to God's judgement, while family

28 Zückert 1768, 61-64; see also Rather 1965, 227, n. 125, and Fox 1987, 10.

29 Richardson 1751, vol. 7, LVII, 206.

30 Richardson 1751, vol. 7, LVII, 206.

31 Richardson 1751, vol. 7, LXXII, 255.

32 Richardson 1751, vol. 7, XCI, 354.

33 For the 'Good Death', see Ariès 1983, 10-13; Atkinson 1992, Introduction; Beaty 1970; McCray Beier 1989, 43-61; Houlbrooke 1998, 167, 203; Jalland 1996, 65-69; Taylor 1651. 
and friends could be dealt with in an orderly will; the death itself could be similarly controlled, with appropriately edifying speeches to those gathered round the bed and a dignified departure to the next life. Richardson inserts Clarissa directly into this discourse, endowing her form of consumption with the very qualities necessary for the perfect good and easy death. Although here she is not 'actually dying', she knows that she will certainly die and, thanks to her generally pain-free body and clear intellect, she can prepare accordingly. God gives Clarissa the disease for which Christians popularly pray.

Clarissa's religious melancholy literally embodies this urge to strain for the spiritual because her extreme weakness, and the fervour of her devotions when at church, were contraries which, pulling different ways (the soul aspiring, the body sinking), tore her tender frame to pieces ${ }^{34}$.

This dichotomous tension between the earthly body and the heavenly soul is particularly suitable to consumption because the flesh falls away as if the body were dematerialising; a consumption of the lungs is all the better as it draws attention to the symbol of the spirit manifested in the breath. Of course Clarissa becomes an angel before she dies ${ }^{35}$.

Richardson's rewriting of Walton's Lives for his own century via melancholy transforms Clarissa into a modern martyr, usurping much of the discourse of the consumptive good death. As a literary mythologist of melancholic femininity, Richardson is rather less radical than he might appear in the sense that he ties woman's fate into secular love even as he reinforces it with the master narrative of Protestant Christianity. All she can do, in Richardson's logic, is die; consequently she turns all her concentration on dying well, or rather 'decently', complaining that Lovelace prevents her from doing this very thing:

he will not let me enter into my Maker's presence with the composure that is required in entering into the drawing-room of an earthly prince! $!^{36}$

Like her holy predecessors, she needs to be calm and composed in her final hours. Yet again the beneficial symptoms of consumption aid her in this process, a symptomatology that she interprets, as Browne had before her, as a sign of divine favour:

if this be dying, said she, there is nothing at all shocking in it. My body hardly sensible of pain, my mind at ease, my intellects clear and perfect as ever. What a good and gracious God have I! For this is what I always prayed for. ${ }^{37}$

34 Richardson 1751, vol. 7, LXXXIII, 260.

35 Richardson 1751, vol. 7, LXXXIII, 254.

36 Richardson 1751, vol. 7, XCVIII, 379.

37 Richardson 1751, vol. 7, CII, 401. 
Even as the literature of sensibility suggested that the suffering individual is too pure for the crudities of this world, it also focused attention, via its basis in the nerves and fibres, on the body itself, in all its subtle responsiveness to the external environment. This new interest in the diseased female body is a logical conclusion to the kinds of ideas being promoted by Cheyne and others in which the most attractive kind of woman is both nervously melancholic and consumptively thin. At another level Clarissa's death moves the discourse of the good and easy death on to a newly aestheticised dimension. Now her 'beautiful death' will become a standard model for depictions of consumption as a beautiful disease: not something that had been claimed for it by the divines of the seventeenth century.

The popular novel Clarissa codes a new and gendered form of melancholy for the mid-eighteenth century, a melancholy that both emerges from established Renaissance traditions of love and religious melancholy and from the new medicine of the nerves as propagated by George Cheyne amongst others. Both in the medical theory and the literary practice, the material unity of man is assumed, although the specific form of that unity varies according to discourses of gender, religion and class. The disease consumption, in its various manifestations, is a consequence of the direct effects of melancholy - for Clarissa a condition of the soul - on the body. The status of melancholy, as this whole publication demonstrates, contradicts the caricature of the Enlightenment as an age of prose, mechanical philosophy and dull materialism. We need to do much more work on the complex relations between body and soul in the hybrid condition of melancholy, but I hope this essay contributes to the debate that the conference on which this book is based has engaged in such a timely fashion.

\section{Bibliography}

Ariès, Philippe, The Hour of our Death (Harmondsworth 1983)

Atkinson, David William, The English ars moriendi (New York 1992)

Barker-Benfield, G. J., The Culture of Sensibility: Sex and Society in Eighteenth-Century Britain (London 1992)

Beaty, N. L., The Craft of Dying: A Study in the Literary Tradition of the 'Ars Moriendi' in England (New Haven 1970)

Bronfen, Elizabeth, Over Her Dead Body: Death, Femininity and the Aesthetic (Manchester 1992)

Brookes, Richard, General Practice of Physic, 2 vols (London 1765)

Browne, Thomas, Religio Medici and other Works, ed. by L. C. Martin (Oxford 1964)

Buchan, William, Domestic Medicine: or, a treatise on the prevention and cure of diseases by regimen and simple medicines (Dublin 1774)

Cheyne, George, George Cheyne: The English Malady (1733), ed. by Roy Porter (London 1991)

- An Essay of health and long life (London 1753)

Dijkstra, Bram, Idols of Perversity: Fantasies of Feminine Evil in Fin-de-Siècle Culture (Oxford 1986) 
Fox, Christopher, 'Defining Eighteenth-Century Psychology: Some Problems and Perspectives', in: Christopher Fox (ed.), Psychology and Literature in the Eighteenth Century (New York 1987) $1-23$

Guerrini, Anita, 'The Hungry Soul: George Cheyne and the Construction of Femininity', Eighteenth Century Studies 32 (1999) 279-291

Houlbrooke, Ralph, Death, Religion, and the Family in England, 1480-1750 (Oxford 1998)

Jalland, Pat, Death in the Victorian Family (Oxford 1996)

Lawlor, Clark/Akihito Suzuki, 'The Disease of the Self: Representations of Consumption 17001830', Bulletin of the History of Medicine 74 (2000) 258-294

Mandeville, Bernard, A Treatise of the Hypochondriack and Hysterick Diseases in Three Dialogues (London 1730 [1711])

McCray Beier, Lucinda, 'The Good Death in Seventeenth-Century England', in: Ralph Houlbrooke (ed.), Death, Ritual and Bereavement (London 1989) 43-61

Mullan, John, Sentiment and Sociability: the Language of Feeling in the Eighteenth Century (Oxford 1988)

Rather, J. L., Mind and Medicine in the Eighteenth Century: A Study based on Herome Gaub's De Regemine Mentis (Berkeley 1965)

Richardson, Samuel, Pamela; or, Virtue Rewarded, ed. by Peter Sabor (Harmondsworth 1985)

- Clarissa, or, the History of a Young Lady, 3rd ed., 8 vols (London 1751)

Rousseau, G. S., 'Nerves, Spirits, and Fibres: Towards Defining the Origins of Sensibility,' in: Brissenden, R. F./J. C. Eade (eds), Studies in the Eighteenth Century (Toronto 1976) 137-157

Schofield, Robert E., Mechanism and Materialism: British Natural Philosophy in an Age of Reason (Princeton 1970)

Spillane, J., The Doctrine of the Nerves (London 1981)

Stephanson, Raymond, 'Richardson's "Nerves": The Physiology of Sensibility in Clarissa', Journal of the History of Ideas 49 (1988) 267-285

Stephens, John, A Practical Treatise on Consumptions (London 1761)

Taylor, Jeremy, The Rules and Exercises of Holy Dying (London 1651)

Whytt, Robert, Observations on the nature, causes and cure of those disorders which have been commonly called Nervous, Hypochondriac, or Hysteric, 2nd ed. (Edinburgh 1765)

Zückert, J. F., Von den Leidenschaften (Berlin 1768) 